\title{
Effects of cell size and specific growth rate on stable carbon isotope discrimination by two species of marine diatom
}

\author{
Rebecca E. Korb ${ }^{1,2, *}$, John A. Raven ${ }^{1}$, Andrew M. Johnston ${ }^{1}$, John W. Leitley ${ }^{2}$ \\ ${ }^{1}$ Department of Biological Sciences, University of Dundee, Dundee DD1 $4 \mathrm{HN}$, United Kingdom \\ ${ }^{2}$ Dunstaffnage Marine Laboratory, PO Box 3, Oban, Argyll PA34 4AD, United Kingdom
}

\begin{abstract}
Effects of cell size and/or specific growth rate were studied in 2 species of marine diatom. the large-celled Ditylum brightwellii and the smaller Chaetoceros calcitrans. Cells were grown as lightlimited continuous cultures to produce a wide range of specific growth rates from $0.12 \mathrm{~d}^{-1}$ in $D$. brightwellii to $1.01 \mathrm{~d}^{-1}$ in $C$. calcitrans. Carbon isotope discrimination $(\Delta)$ values, relative to source $\delta^{13} \mathrm{C}$ of dissolved inorganic carbon (DIC), showed no relationship to specific growth rate within species. When examined interspecifically there was some evidence that growth rate or cell size affected the ${ }^{1.3} \mathrm{C} /{ }^{12} \mathrm{C}$ ratios of the diatoms. At each photon flux density (PFD) used for growth, the specific growth rate of $C$. calcitrans was at least twice that of $D$. brightwellit. Values of $\Delta$ were greater in $D$. brightwellii at PFDs of 5,20 and $40 \mu \mathrm{mol}$ photon $\mathrm{m}^{-2} \mathrm{~s}^{-1}$. These data are in agreement with a hypothesis stating that fastergrowing diatoms should be enriched in ${ }^{13} \mathrm{C}$. However, at the highest growth irradiance of $60 \mu \mathrm{mol} \mathrm{m} \mathrm{m}^{-2}$ $\mathrm{s}^{-1}, \Delta$ values were higher in $C$. calcitrans than in $D$. brightwellii. Source $\delta^{13} \mathrm{C}$ : values varied between individual cultures and demonstrated the importance of directly measuring the $\delta^{13} \mathrm{C}$ of DIC. The value of physiological data in fully interpreting the stable carbon isotope ratios of diatoms is also discussed.
\end{abstract}

KEY WORDS: Carbon isotope discrimination - Cell size Chdetocesos calcitrans Ditylum brightwellii Photon flux density. Specific growth rate

\section{INTRODUCTION}

Stable carbon isotope ratios of terrestrial plants are well defined and understood, with $\delta^{13} \mathrm{C}$ values being primarily determined by the main carboxylating enzymes involved with photosynthesis (Park \& Epstein 1960). $\mathrm{C}_{3}$ plants have typical $\delta^{13} \mathrm{C}$ values of -20 to $-32 \%$ and $\mathrm{C}_{4}$ plants $\delta^{13} \mathrm{C}$ values of -9 to $-17 \%$ (O'Leary 1981). The isotopic composition of CAM (crassulacean acid metabolism) plants will reflect operation of the different carboxylation pathways, thus when they function strictly in the $\mathrm{C}_{3}$ mode they have $\delta^{13} \mathrm{C}$ values near those of $\mathrm{C}_{3}$ plants while plants engaging in only $\mathrm{C}_{4}$ fixation will have $\delta^{13} \mathrm{C}$ values near those of $\mathrm{C}_{4}$ plants. However, in the aquatic environment, algal species show a wide variation in ${ }^{13} \mathrm{C} /{ }^{12} \mathrm{C}$ ratios.

- Present address: MSRC, State University of New York, Stony Brook, New York 11794-5000, USA
For cultures of marine phytoplankton, an essentially continuous range of values from -6 to $-30 \%$ has been reported (Degens et al. 1968a, b, Wong \& Sackett 1978 Descolas-Gros \& Fontugne 1990, Falkowski 1991 Johnston \& Raven 1992; work on diatoms is reviewed by Fry 1996).

Recent work has suggested that factors such as growth rate and cell size might influence the carbon isotope ratios in marine phytoplankton (Muscatine et al. 1989, Fry \& Wainwright 1991, Takahashi et al. 1991, Laws et al. 1995). During growth, small cells with high specific growth rates may use $\mathrm{CO}_{2}$ rapidly. If the rate of photosynthetic carbon fixation is much faster than the replacement of inorganic carbon, for example from $\mathrm{CO}_{2}$ in air, then isotopic equilibration between the various dissolved inorganic carbon species may not be reached. Fixation of almost all available $\mathrm{CO}_{2}$ would result in limited fractionation and the cells would become enriched in ${ }^{13} \mathrm{C}$ (Deuser et al. 1968, Rau et al. 
1992). A culture of large cells that have slow growth rates, with the same inoculum of algal biomass per unit of culture medium as small cells, should be unable to cause such a ${ }^{12} \mathrm{C}$ depletion and are thus expected to have more negative $\delta^{13} \mathrm{C}$ values than smaller cells.

Alternatively, larger cells, with thicker boundary layers than smaller cells, may have more positive $\delta^{13} \mathrm{C}$ values. All solid objects in fluids will have unstirred layers (boundary layers) surrounding them (Raven 1994). Exchange of nutrients will be by molecular diffusion. The carbon pool in the boundary layer will represent that in a semi-closed system (Smith \& Walker 1980). In cells relying on $\mathrm{CO}_{2}$ diffusion for photosynthesis, a thicker boundary layer should cause greater diffusion of $\mathrm{CO}_{2}$ and assimilation of ${ }^{13} \mathrm{C}$ which would normally be discriminated against (France 1995).

The purpose of this study was to investigate the influence that growth rate and cell size may have on the $\delta^{13} \mathrm{C}$ values of the large-celled Ditylum brightwellii and the small-celled Chaetoceros calcitrans. Lightlimited continuous cultures were used to alter growth rates of the diatoms. The range of irradiances used in this study was characteristic of the photosynthetically active radiation found in the lower regions of the euphotic zone in stratified oceanic areas (Kirk 1994).

\section{MATERIALS AND METHODS}

Cultures. Cultures of Chaetoceros calcitrans and Ditylum brightwellii were obtained from the Provasoli-Guillard Centre for Culture of Marine Phytoplankton (CCMP, Maine, USA). The diatoms were grown in lightlimited continuous cultures. At steady state, the specific growth rate of cells equals the dilution rate of the culture and there is no change in cell concentration. Dilution rate is defined as $D=f / v$, where $f$ is the flow rate $\left(\mathrm{cm}^{3} \mathrm{~d}^{-1}\right)$ and $v$ is the volume of the culture $\left(\mathrm{cm}^{3}\right)$ which was $1 \mathrm{dm}^{3}$ in this study. Photon flux density (PFD), and consequently specific growth rate, was controlled by altering the distance of a fluorescent lamp from the culture vessel and was set at 5,20,40 or $60 \mu \mathrm{mol} \mathrm{m}^{-2} \mathrm{~s}^{-1}$ at the surface of the vessel. Cultures were aerated from cylinders of compressed air (BOC Gases, Surrey, UK). A glass sparger (BDH Laboratory Supplies, Poole, UK) and magnetic stirrer ensured that the culture and medium were well mixed and prevented settling.

The continuous cultures were grown in a constanttemperature room maintained at $18^{\circ} \mathrm{C}$ and under constant illumination. When algal samples were removed for experimental purposes, the volume in the culture vessel was allowed to reach $1 \mathrm{dm}^{3}$ and a steady state achieved before further samples were withdrawn.

Checks of $\mathrm{pH}$ and dissolved inorganic carbon (DIC) in the culture medium were made when samples were withdrawn for stable carbon isotope analysis. Average values of $\mathrm{pH}$ were approximately 8.40 for both species and average [DIC] was $1.99 \mathrm{~mol} \mathrm{~m} \mathrm{~m}^{-3}$ for Chaetoceros calcitrans and $2.19 \mathrm{~mol} \mathrm{~m}^{-3}$ for Ditylum brightwellii.

Stable carbon isotope analysis. Samples for determination of organic carbon isotope ratios were collected by removing $150 \mathrm{~cm}^{3}$ of culture. Cells were pelleted using a bench centrifuge $(3000 \times g$ for $5 \mathrm{~min})$, washed twice in fresh, sterile seawater, then washed twice in distilled water to remove inorganic carbon. Samples were suspended in $20 \mathrm{~mm}^{3}$ distilled water, transferred to tin boats and dried overnight at $80^{\circ} \mathrm{C}$. The $\delta^{13} \mathrm{C}$ of particulate organic carbon was measured on a VG SIRA Series II isotope ratio mass spectrometer with a Carlo-Erba CHN analyser as the combustion unit.

For $\delta^{13} \mathrm{C}$ determination of source DIC, $20 \mathrm{~cm}^{3}$ samples were acidified in $10 \mathrm{~cm}^{3}$ of $8 \mathrm{kmol} \mathrm{m}^{-3}$ phosphoric acid and the resulting $\mathrm{CO}_{2}$ was collected cryogenically using a liquid nitrogen trap. A helium gas stream was used as a carrier gas and this together with the liberated $\mathrm{CO}_{2}$ was pulled into an evacuated collecting tube using a rotary vacuum high pressure pump. Source $\delta^{13} \mathrm{C}$ values were measured on a Europa 20/20 mass spectrometer.

Carbon isotope discrimination $(\Delta)$ was calculated as:

$$
\Delta=\frac{\delta^{13} C_{\text {source }}-\delta^{13} C_{\text {product }}}{1+\delta^{13} C_{\text {product }}}
$$

\section{RESULTS}

\section{Light-limited growth characteristics}

Specific growth rates for Chaetoceros calcitrans, when grown under light limitation, ranged from 0.29 to $1.01 \mathrm{~d}^{-1}$. In Ditylum brightwellii, the lowest growth rate was $0.12 \mathrm{~d}^{-1}$ and the highest $0.58 \mathrm{~d}^{-1}$. For any given irradiance, the maximum specific growth rate of C. calcitrans was at least twice that of $D$. brightwellij (Fig. 1).

\section{Stable carbon isotope ratios}

In the continuous cultures, the $\delta^{13} \mathrm{C}$ of the source DIC ranged from -4.69 to $+0.57 \%$. Measurements of source $\delta^{13} \mathrm{C}$ were made for each organic $\delta^{13} \mathrm{C}$ sample taken and used to calculate $\Delta$ at each specific growth rate (Table 1).

\section{Intraspecific variation in $\delta^{13} \mathrm{C}$}

Mean $\delta^{13} \mathrm{C}$ values of the organic material of Chaetoceros calcitrans became slightly more negative with 


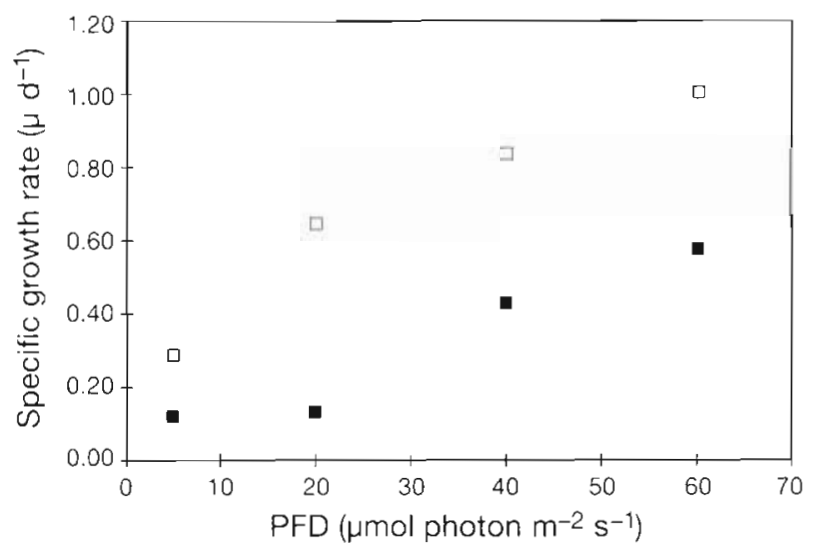

Fig. 1 Specific growth rates of continuous cultures of (D) Chaetoceros calcitrans and (a) Ditylum brightwellii at varying PFDs at $18^{\circ} \mathrm{C}$. Each point is the mean of at least 10 measurements

decreasing growth rate: from $-20.60 \%$ at $1.01 \mathrm{~d}^{-1}$ to $-22.41 \%$ at $0.29 \mathrm{~d}^{-1}$ (Table 1). In Ditylum brightwellii organic $\delta^{13} \mathrm{C}$ showed no association with specific growth rate with values ranging from -21.82 to $-24.94 \%$. When the results were expressed as discrimination values relative to measured source $\delta^{13} \mathrm{C}$ of DIC, there was no relationship with specific growth rate (Fig. 2) in either C. Calcitrans $\left(r^{2}=0.24 ; p>0.05\right)$ or D. brightwellii $\left(\mathrm{r}^{2}=0.09 ; \mathrm{p}>0.05\right)$.

\section{Interspecific variation in $\delta^{13} \mathrm{C}$}

When the mean discrimination values for both diatoms at all light levels were examined, significant
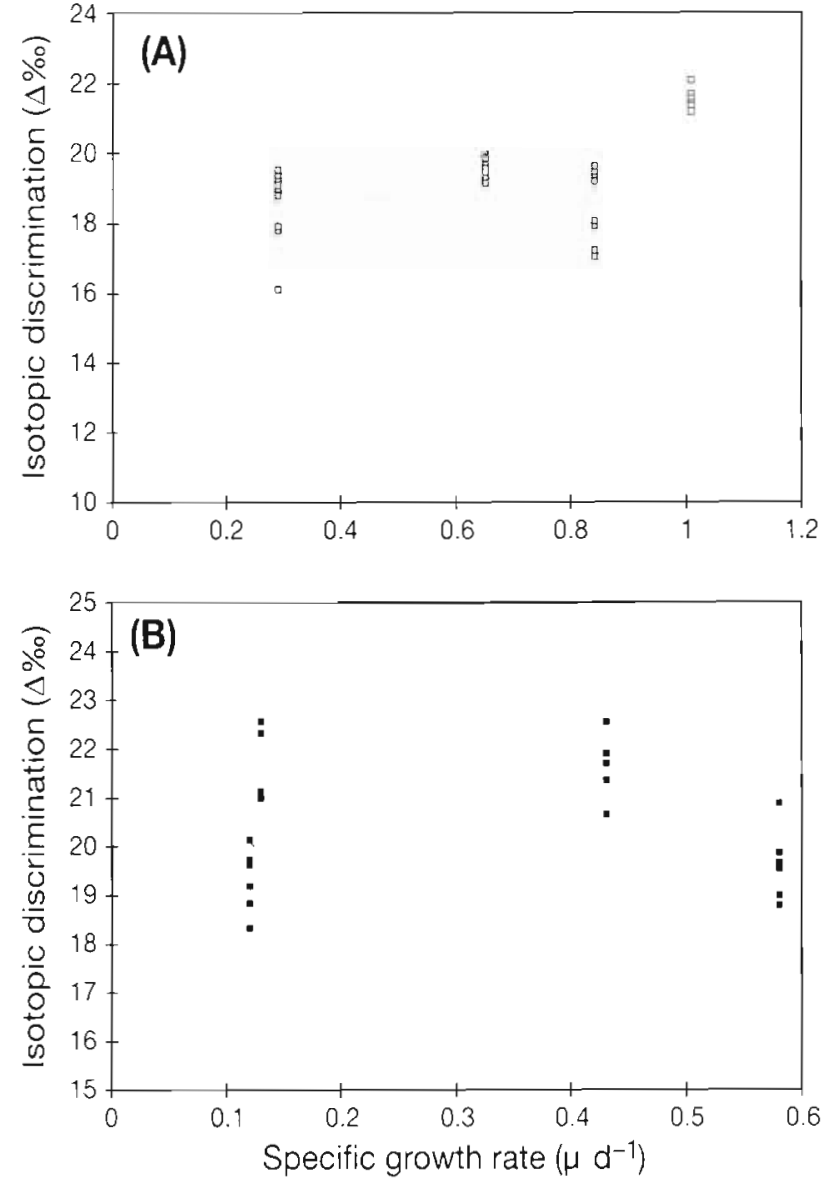

Fig. 2. Isotopic discrimination in continuous cultures of $(A)$ Chaetoceros calcitrans and (B) Ditylum brightwellii at varying specific growth rates at $18^{\circ} \mathrm{C}$. Dotted lines indicate regression between isotope discrimination and specific growth rate
Table 1. Organic $\delta^{13} \mathrm{C}$ and $\Delta$, relative to source DIC $\delta^{13} \mathrm{C}$, for Chaetoceros calcitrans and Ditylum brightwellii grown as continuous cultures at various specific growth rates $(\mu)$

\begin{tabular}{|c|c|c|c|c|}
\hline Species & $\mu\left(d^{-1}\right)$ & $\delta^{13} \mathrm{C}$ organic $(\% n)$ & $\delta^{13} \mathrm{C}$ source $(\%)$ & $\Delta(\%)$ \\
\hline \multirow[t]{4}{*}{ Chaetoceros calcitrans } & 1.01 & $\begin{array}{c}-20.60( \pm 0.24) \\
n=8\end{array}$ & $\begin{array}{l}+0.57 \\
\mathrm{n}=2\end{array}$ & 21.61 \\
\hline & 0.84 & $\begin{array}{c}-21.31( \pm 0.91) \\
n=10\end{array}$ & $\begin{array}{c}-3.14( \pm 1.35) \\
n=8\end{array}$ & 18.57 \\
\hline & 0.65 & $\begin{array}{c}-22.19( \pm 0.27) \\
n=10\end{array}$ & $\begin{array}{c}-2.88( \pm 1.19) \\
n=6\end{array}$ & 19.75 \\
\hline & 0.29 & $\begin{array}{c}-22.41( \pm 0.95) \\
n=10\end{array}$ & $\begin{array}{c}-4.36( \pm 0.87) \\
n=6\end{array}$ & 18.46 \\
\hline \multirow[t]{4}{*}{ Ditylum brightwellii } & 0.58 & $\begin{array}{c}-21.82( \pm 0.62) \\
n=10\end{array}$ & $\begin{array}{c}-2.49( \pm 0.95) \\
n=4\end{array}$ & 19.76 \\
\hline & 0.43 & $\begin{array}{c}-24.94( \pm 0.60) \\
n=6\end{array}$ & $\begin{array}{c}-3.41( \pm 1.05) \\
n \simeq 8\end{array}$ & 21.61 \\
\hline & 0.13 & $\begin{array}{c}-24.18( \pm 0.60) \\
n=10\end{array}$ & $\begin{array}{c}-2.95( \pm 1.09) \\
n=9\end{array}$ & 21.74 \\
\hline & 0.12 & $\begin{array}{c}-23.35( \pm 0.63) \\
n=10\end{array}$ & $\begin{array}{c}-4.69( \pm 1.04) \\
n=8\end{array}$ & 19.22 \\
\hline
\end{tabular}

differences were found between the data sets (ANOVA, $\mathrm{p}<0.05$ ). At PFDs of 20,40 and $60 \mu \mathrm{mol} \mathrm{m} \mathrm{m}^{-2} \mathrm{~s}^{-1}$ carbon isotope discrimination was significantly different between Chaetoceros calcitrans and Ditylum brightwellii (2-sample Student's $t$-tests, all p values $<0.05$ ).

At each PFD, the specific growth rate of Chaetoceros calcitrans was greater than Ditylum brightwelli (Fig. 1). However, there was no clear relationship between cell size or specific growth rate and ${ }^{13} \mathrm{C} /{ }^{12} \mathrm{C}$ ratios At $60 \mu \mathrm{mol} \mathrm{m} \mathrm{m}^{-2} \mathrm{~s}^{-1}$, the mean $\Delta$ value was $21.61 \%$ for the small diatom C. calcitrans and $19.76 \%$ for the large D. brightwellii (Table 1, Fig. 3). These data are inconsistent with the hypothesis that larger, slower-growing 


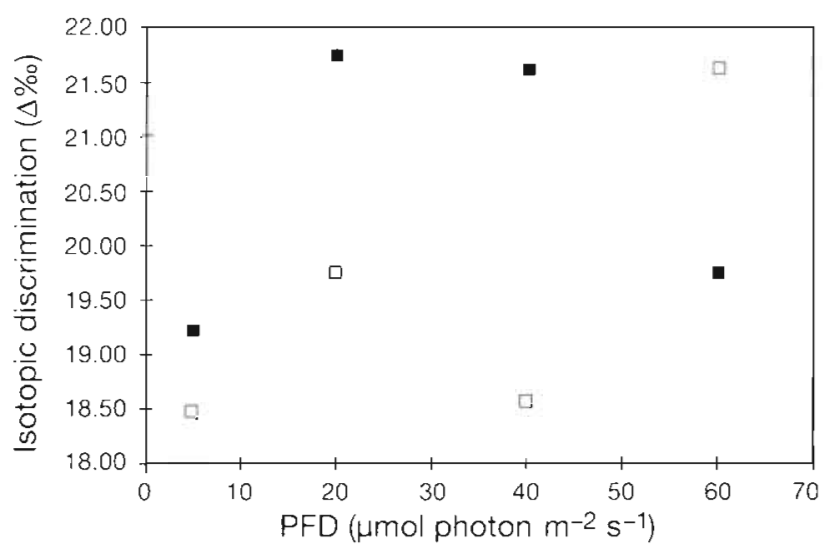

Fig. 3. Isotopic discrimination in continuous cultures of (ㅁ) Chaetoceros calcitrans and (-) Ditylum brightwellii at varying PFDs at $18^{\circ} \mathrm{C}$. Each point is the mean of at least 6 replicates

diatoms should have greater ${ }^{13} \mathrm{C}$ discrimination, but are consistent with a boundary layer effect which would give less isotopic fractionation in the larger cells.

At lower PFDs and associated growth rates, $\delta^{13} \mathrm{C}$ values were in agreement with the hypothesis that fastergrowing diatoms should be enriched in ${ }^{13} \mathrm{C}$. At light levels of 5,20 and $40 \mu \mathrm{mol} \mathrm{m} \mathrm{m}^{-2} \mathrm{~s}^{-1}$, Chaeoceros calcitrans had a higher specific growth rate than Ditylum brightwellii (Fig. 1) and showed less discrimination against ${ }^{13} \mathrm{C}$ (Fig. 3, Table 1).

\section{DISCUSSION}

Growth rate and cell size effects have been shown to account for isotopic variability in diatoms (Fry \& Wainwright 1991, Laws et al. 1995), in zooxanthellae (Muscatine et al. 1989), chlorophytes (Takahashi et al. 1991) and phytoplankton blooms (Nakatsuka et al. 1992). In this study, if a growth rate effect were to outweigh a boundary layer effect then it was expected that carbon isotope discrimination would firstly increase with cell size and secondly decrease with specific growth rates in the marine diatoms Chaetoceros calcitrans and Ditylum brightwellit. From the results of these experiments there was no clear association between carbon isotope discrimination and specific growth rate when the diatoms were examined separately. Similar results were obtained by Hinga et al. (1994) working on Skeletonema costatum and Emiliania huxleyi (2 species of phytoplankton of approximately the same size). They concluded that the range of growth rates used in their study, relative to the possible range, was too small to make the effect noticeable. This was not the case in this study where the diatoms were cultured over a wide range of growth rates.
The theoretical relationship between specific growth rate and $\delta^{13} \mathrm{C}$ is based on cells obtaining their inorganic carbon by diffusive entry of $\mathrm{CO}_{2}$. A difficulty with this hypothesis is the possibility that microalgal cells use $\mathrm{HCO}_{3}^{-}$as well as $\mathrm{CO}_{2}$. The use of $\mathrm{HCO}_{3}$ could lead to isotope shifts, unassociated with changes in growth rate, due to the fact that at isotopic equilibrium $\mathrm{HCO}_{3}{ }^{-}$is enriched in ${ }^{13} \mathrm{C}$. As $\mathrm{CO}_{2}$ is the species used by ribulose bisphosphate carboxylase-oxygenase (Kerby \& Raven 1985), carbonic anhydrase (CA) is required to convert $\mathrm{HCO}_{3}{ }^{-}$to $\mathrm{CO}_{2}$. If the conversion of $\mathrm{HCO}_{3}{ }^{-}$to $\mathrm{CO}_{2}$ occurs intracellularly, and the exchange of $\mathrm{HCO}_{3}^{-}$(and even $\mathrm{CO}_{2}$ ) across the plasmalemma is slow so that heavy residual ${ }^{13} \mathrm{C}$ does not exit from the cell, then the $\mathrm{CO}_{2}$ available for photosynthesis would be enriched in ${ }^{13} \mathrm{C}$ and $\Delta$ would be smaller than in the case of purely diffusional transport (Sharkey \& Berry 1985). However, if the dehydration of $\mathrm{HCO}_{3}{ }^{-}$occurs at the cell surface with $\mathrm{CA}_{1}$ then the $\mathrm{CO}_{2}$ entering the cell would be isotopically similar to the external $\mathrm{CO}_{2}$. This is because the equilibrium fractionation of $\mathrm{HCO}_{3}{ }^{-}$and $\mathrm{CO}_{2}$ is closely similar to the fractionation associated with the CA-mediated conversion of $\mathrm{HCO}_{3}{ }^{-}$to $\mathrm{CO}_{2}$ (Mook et al. 1974, O'Leary 1992)

Studies on the sources of inorganic carbon for photosynthesis in Chaetoceros calcitrans and Ditylum brightwellii indicate that in aerated, resource-saturated, continuous cultures with a pH of 8.40 and DIC of $2 \mathrm{~mol} \mathrm{~m} \mathrm{~m}^{-3}$. CA may be involved in photosynthetic carbon assimilation ( $\mathrm{R}$. Korb unpubl. data). If the $\mathrm{CA}$ is located extracellularly, $\mathrm{CO}_{2}$ converted from $\mathrm{HCO}_{3}$ may be transported into the cell. The $\Delta$ values of the diatoms are consistent with, but do not prove, conversion of $\mathrm{HCO}_{3}^{-}$to $\mathrm{CO}_{2}$ outside the cell followed by diffusion of $\mathrm{CO}_{2}$ into the cells with a relatively small diffusion limitation (Raven et al. 1995). It is possible that at all the growth rates examined in the present study, $\mathrm{CO}_{2}$ supply was adequate and no large fractional limitation due to transport, which would result in low $\Delta$ values, was observed. Thus $\Delta$ values do not increase with increasing growth rate in. either species.

When a comparison is made between Chaetoceros calcitrans and Ditylum brightwellii, $\Delta$ is greater in the larger, slower-growing diatom at PFDs of 5,20 and $40 \mu \mathrm{mol} \mathrm{m} \mathrm{m}^{-2} \mathrm{~s}^{-1}$. These data support the hypothesis that larger cells with slower growth rates will lead to increased carbon isotope discrimination. However, the precise mechanism of ${ }^{13} \mathrm{C}$ enrichment in cells of different sizes, which obtain their inorganic carbon for photosynthesis by diffusive entry of $\mathrm{CO}_{2}$ following the CA-catalysed conversion of $\mathrm{HCO}_{3}{ }^{-}$, is unclear In semiclosed systems, irrespective of whether cells obtain. their inorganic carbon source by diffusive entry of $\mathrm{CO}_{2}$ or active transport, cell size and specific growth rate may still have effects on isotopic discrimination. Where 
the growth rate of phytoplankton is fast, relative to the equilibrium fractionation of $\mathrm{HCO}_{3}{ }^{-}$and $\mathrm{CO}_{2}$, the resulting DIC pool may become depleted in ${ }^{12} \mathrm{C}$ leading to ${ }^{13} \mathrm{C}$ enrichment and subsequent formation of organic carbon. The possibility of biologically mediated isotope effects on ocean DIC was used by Deuser (1970) to interpret elevated plankton $\delta^{13} \mathrm{C}$ in a semiclosed system. Such effects cannot account for the results obtained in this study as the continuous cultures used to grow $C$. calcitrans and $D$. brightwellii were not semi-closed systems in terms of $\mathrm{CO}_{2}$ availability. Although $\left[\mathrm{CO}_{2}(\mathrm{aq})\right]$ was only approximately $5 \mathrm{mmol} \mathrm{m} \mathrm{m}^{-3}$, due to the relatively high $\mathrm{pH}$, the cultures were well stirred and aerated, ensuring good diffusion of $\mathrm{CO}_{2}$ into the medium and a constant re-supply of ${ }^{12} \mathrm{C}$ to the system.

Effects of cell size and subsequent boundary layer thickness may be more important than specific growth rate in influencing stable carbon isotope ratios when photosynthesis is occurring in an open system (in terms of $\mathrm{CO}_{2}$ and ${ }^{12} \mathrm{C}$ availability). A species of a particular size should have a boundary layer with a certain thickness and a source $\delta^{13} \mathrm{C}$ value which will remain constant irrespective of growth rate. If the stagnant boundary layer surrounding a diatom acts as a semiclosed system and the cell is obtaining $\mathrm{CO}_{2}$ purely by diffusion, then it is possible that a small, fast-growing cell may rapidly use $\mathrm{CO}_{2}$, as it dissociates from bicarbonate in the boundary layer, before isotopic equilibrium can be attained. France (1995) found that phytoplankton having thicker stagnant boundary layers, for example benthic algae compared to algae from highly turbulent conditions, resulted in smaller isotopic discrimination. In the present study, $\Delta$ values were greater in Ditylum brightwellif (with the thicker boundary layer) than in Chaetoceros calcitrans only when the cells were grown at a PFD of $60 \mu \mathrm{mol} \mathrm{m} \mathrm{m}^{-2} \mathrm{~s}^{-1}$. In addition, at similar specific growth rates of $0.65 \mathrm{~d}^{-1}$ for C. Calcitrans and $0.58 \mathrm{~d}^{-1}$ for $D$. brightwellii there is little difference in $\Delta$ values $(19.76$ and $19.75 \%$, respectively). Therefore, it would appear that boundary layer thickness has little effect on stable carbon isotope discrimination in these diatoms.

Isotopic variation in source carbon supply is often variable in aquatic environments (Boutton 1991) and so discrimination values are typically used. Often, it is assumed that the $\delta^{13} \mathrm{C}$ of source samples is relatively constant and a single value, either measured directly or estimated from the equations of Mook et al. (1974), is used to calculate $\Delta$ values. As the $\delta^{13} \mathrm{C}$ of the source DIC varied between individual cultures and individual growth rates in the present study, $\Delta$ was calculated on an individual growth rate basis. Source $\delta^{13} \mathrm{C}$ values differ as the measurements were made at different times and the isotopic composition of the compressed air changed slightly with different cylinders. Had we used 1 measured or estimated source $\delta^{13} \mathrm{C}$ value, the resulting discrimination values would have been markedly different. For example, a $\mathrm{CO}_{2}$ source value of $-7 \%$ used to calculate $\Delta$ would result in greater discrimination in the larger diatom than in the small diatom at all growth rates and PFDs, as organic carbon $\delta^{13} \mathrm{C}$ was always greater in Ditylum brightwellii (Table 1). Direct measurements of the $\delta^{13} \mathrm{C}$ of source inorganic carbon, relative to each organic $\delta^{13} \mathrm{C}$ sample taken, are imperative to allow comparisons with other studies.

The data from this study are in agreement with the hypothesis that small, fast-growing diatoms are enriched in ${ }^{13} \mathrm{C}$ in comparison to larger, slower-growing diatoms. However, carbon isotope discrimination values showed no relationship to specific growth rate within species. In addition, boundary layer thickness did not appear to affect $\Delta$ values. At present, there is no theory to account for a relationship between stable carbon isotope discrimination and growth rate for cells in open systems where transport of $\mathrm{CO}_{2}$ is not limiting for photosynthesis. Further studies, supported by physiological data in the form of inorganic carbon assimilation and measurements of experimental source $\delta^{13} \mathrm{C}$, are needed to determine the effects that cell size and specific growth rate have on the carbon isotopic signatures of phytoplankton

Acknowledgements. This study was supported by a NERC CASE studentship. We thank Peter Saville and Dr A. Patel for assistance with mass spectrometry.

\section{LITERATURE CITED}

Boutton TW (1991) Stable carbon isotope ratıos of natural materials: II. Atmospheric, terrestrial, marine and freshwater environments. In: Coleman DC. Fry B (eds) Carbon isotope techniques. Academic Press Inc., San Diego, p 201-218

Degens ET, Behrendt M, Gotthardt B, Reppmann E (1968a) Metabolic fractionation of carbon isotopes in marine plankton-II. Data on samples collected off the coast of Peru and Ecuador. Deep Sea Res 15:11-20

Degens ET, Guillard RRL, Sackett WM, Hellebust JA (1968b) Metabolic fractionation of carbon isotopes in marine plankton-1. Temperature and respiration experiments. Deep Sea Res 15:1-9

Descolas-Gros C, Fontugne M (1990) Stable carbon isotope fractionation by marine phytoplankton during photosynthesis. Plant Cell Environ 13:207-218

Deuser WG (1970) Isotopic evidence for diminishing supply of available carbon during diatom bloom in the Black Sea. Nature 225:1069-1071

Deuser WG, Degens ET, Guillard RRL (1968) Carbon isotope relationships between plankton and seawater. Geochim Cosmochim Acta 32:657-660

Falkowski PG (1991) Species variability in the fractionation of ${ }^{13} \mathrm{C}$ and ${ }^{12} \mathrm{C}$ by marine phytoplankton. J Plankton Res 13 $21-28$

France FL (1995) Carbon-13 enrichment in benthic compared 
to planktonic algae: foodweb implications. Mar Ecol Prog Ser 124:307-312

Fry $\mathrm{B}(1996){ }^{13} \mathrm{C} /{ }^{12} \mathrm{C}$ fractionation by marine diatoms. Mar Ecol Prog Ser 134:283-294

Fry B, Wainwright SC (1991) Diatom sources of ${ }^{13} \mathrm{C}$-rnch carbon in marine food webs. Mar Ecol Prog Ser 76:149-157

Hinga KR, Arthur MA, Pilson MEQ, Whitaker D (1994) Carbon isotope fractionation by marine phytoplankton in culture: the effects of $\mathrm{CO}_{2}$ concentration, $\mathrm{pH}$, temperature and species. Global Biogeochem Cycles 8:91-102

Johnston AM, Raven JA (1992) Effect of aeration rates on growth rates and natural abundance of ${ }^{13} \mathrm{C} /{ }^{12} \mathrm{C}$ ratio of Phaeodactylum tricornutum. Mar Ecol Prog Ser 87:295-300

Kerby NW, Raven JA (1985) Transport and fixation of inorganic carbon by marine algae. Adv Bot Res 11:71-123

Kirk JTO (1994) Light and photosynthesis in aquatic ecosystems. Cambridge University Press, Cambridge

Laws EG, Popp BN, Bidigare RR Kennicut MC, Macko SA (1995) Dependence of phytoplankton carbon isotopic composition on growth rate and $\left[\mathrm{CO}_{2}\right]$ aq.: theoretical considerations and experimental results. Geochim Cosmochim Acta 59:1131-1138

Mook WG, Bommerson JC, Staverman WH (1974) Carbon isotope fractionation between dissolved bicarbonate and gaseous carbon dioxide. Earth Planet Sci Lett 22:169-176

Muscatine L, Porter JW, Kaplan IR (1989) Resource partitioning by reef corals as determined from stable isotope composition. I. $\delta^{13} \mathrm{C}$ of zooxanthellae and animal tissue versus depth. Mar Biol 100:185-193

Nakatsuka T, Handa N, Wada E, Wong CS (1992) The dynamic changes of stable carbon isotopic ratios of carbon and nitrogen in suspended and sedimented particulate organic matter during a phytoplankton bloom. J Mar Res 50:267-298

O'Leary MH (1981) Carbon isotope fractionation in plants.

This article was submitted to the editor
Phytochemistry (Oxf) 20:552-567

O'Leary MH, Madhaven S, Paneth P (1992) Physical and chemical basis of carbon isotope fractionation in plants Plant Cell Environ 15:1099-1104

Park R, Epstein S (1960) Carbon isotope fractionation during photosynthesis. Geochim Cosmochim Acta 21:110-126

Rau GH, Takahashi T, Des Marais DJ, Martin JH (1992) The relationship between $\delta^{13} \mathrm{C}$ of organic matter and $\left[\mathrm{CO}_{2}(\mathrm{aq})\right]$ in ocean surface water data from a JGOFS site in the northeast Atlantic Ocean and a model. Geochim Cosmochim Acta 56:1413-1419

Raven JA (1994) Why are there no picoplankton $\mathrm{O}_{2}$ evolvers with volumes less than $10^{-19} \mathrm{~m}^{3}$ ? J Plankton Res 16 : $565-580$

Raven JA, Walker DI, Johnston AM, Handley LL, Kübler JE (1995) Implications of ${ }^{13} \mathrm{C}$ natural abundance measurements for photosynthetic performance by marine macrophytes in their natural environment. Mar Ecol Prog Ser 123:193-205

Sharkey TD, Berry JA (1985) Carbon isotope fractionation of algae as influenced by an inducible $\mathrm{CO}_{2}$ concentrating mechanism. In: Lucas WJ, Berry JA (eds) Inorganic carbon uptake by aquatic photosynthetic organisms. American Society of Plant Physiologists, Rockville, MD, p 389-401

Smith FR, Walker NA (1980) Photosynthesis by aquatic plants: effects of unstirred layer in relation to assimilation of $\mathrm{CO}_{2}$ and $\mathrm{HCO}_{3}{ }^{-}$to carbon isotopic discrimination. New Phytol 86:245-259

Takahashi K, Wada E, Sakamoto M (1991) Relationship between carbon isotope discrimination and the specific growth rate of green alga Chlamydomonas reinhardtit. Jpn J Limnol 52:105-112

Wong WW, Sackett WM (1978) Fractionation of stable carbon isotopes by marine phytoplankton. Geochim Cosmochim Acta 42:1809-1815

Manuscript first received: April 4, 1996

Revised version accepted: August 23, 1996 